\title{
A Life of Their Own: Women's Mid-life Quest in Contemporary Irish Women's Short Stories
}

\author{
Ann Wan-lih Chang \\ Shih-chien University, Kaohsiung Campus, Taiwan
}

Copyright (c) 2016 by Ann Wan-lih Chang. This text may be archived and redistributed both in electronic form and in hard copy, provided that the author and journal are properly cited and no fee is charged for access.

\begin{abstract}
This essay focuses on the motif of quest, as initiated by older or middle-aged women and depicted in stories by Clare Boylan, Éilís Ní Dhuibhne, Stella Mahon, Mary Dorcey and Marilyn McLaughlin in the 1980s and 90s. Throughout the western literary canon the quest motif recurs in myths, legends or genres such as rite-of-passage novels, in which a hero (seldom a heroine) is encouraged to prove his own value through a series of tests. Within this tradition, a woman's quest is usually one involving a process which shapes her into the contemporary norms of social conformity essentially losing or sublimating the self rather than developing or expressing the potential of the self. Notwithstanding the traditional depictions of a female quest in which loss and self-sacrifice are characteristic, representations of Irish women in the stories explored in this essay demonstrate heroines whose quest leads them to a kind of awakening and enlightenment. The heroine in Irish women's stories engages in subversion of the social norm as part of an attempt to reconcile with residual trauma from the past, or with inner conflicts which have left her feeling alienated from accepted social conventions and expectations in respect of women. Irish female writers illustrate through their narrative a latent power to challenge and to subvert the traditionally accepted and dominant patriarchal ideology of Irish society.
\end{abstract}

Keywords: Irish Feminism, Irish Short Story, Rebellious Women, Transformation, Quest.

Resumen. Este ensayo se centra en el motivo de la búsqueda, iniciada por mujeres mayores o de mediana edad en relatos de Clare Boylan, Éilís Ní Dhuibhne, Stella Mahon, Mary Dorcey y Marilyn McLaughlin de la década de los 1980 y 1990. En el canon literario occidental el motivo de la búsqueda se repite en mitos, leyendas o géneros como la novela de iniciación, en los que un héroe (rara vez una heroína) debe demostrar su valor a través de una serie de pruebas. Dentro de esta tradición, el proceso de búsqueda femenina suele moldear a la mujer para que acate las normas sociales del momento, lo cual implica esencialmente perder o sublimar el yo en lugar de desarrollar o expresar todo su potencial. Aun cuando la pérdida y sacrificio por parte de la mujer son elementos frecuentes en historias tradicionales, las representaciones de mujeres irlandesas en los relatos analizados en este ensayo presentan heroínas cuya búsqueda les lleva a una especie de despertar y progresión. Como parte de un intento de sobreponerse a traumas residuales del pasado, o conflictos internos que la han alienado de las convenciones y expectativas sociales en relación a la mujer, la heroína de historias de mujeres irlandesas tiende a subvertir la norma social. Las escritoras irlandesas ilustran a través de su narrativa un poder latente para cuestionar y subvertir la ideología patriarcal tradicionalmente aceptada y dominante en la sociedad irlandesa.

Palabras clave. Feminismo irlandés, relato corto irlandés, mujeres rebeldes, transformación, búsqueda. 


\section{Introduction: The Lonely Other Voice}

There have been some notable, if gradual, changes in many aspects of Irish women's role and life in general since "the other voice" emerged in Irish society in the post-Eamon De Valera period from the 1960s. It is evident, possibly inevitable, that these changes in Irish women's lives are echoed in contemporary Irish women's stories, some writers of which are self-declared feminists or have engaged actively with the Irish women's movement. ${ }^{1}$ Consequently, their literary works tend to be gynocentric, concerned overtly with women's issues and seek explicitly to give voice to women's quest for justice within maledominated Irish society. This essay evaluates a recurrent motif in stories by Clare Boylan, Éilís Ní Dhuibhne, Stella Mahon, Mary Dorcey and Marilyn McLaughlin, the motif of "quest". As opposed to the traditionally male genre of the "monomyth" or "Bildungsroman", Irish women's quest motif is about a heroine who embarks on a different kind of adventure with the aim of achieving a different kind of goal. ${ }^{2}$ This female quest involves subversion of the social norm, rebellion against a socially prescribed role and destiny, and reclamation of a lost place within Irish society. This essay argues that Irish women's stories serve both as a vibrant narrative genre within Irish literary tradition, and as a strategic device by Irish women writers who are seeking to engage with a collective, and evolving, Irish feminist awareness. Typically, such stories focus on women who start by accepting passively a

1. Some Irish female writers are in fact active feminists or have been engaged with the women's movement such as Maeve Kelly, Nuala O'Faolain, Nell McCafferty, Mary Dorcey or Evelyn Conlon. Kelly dedicates her time to supporting women who are victims of domestic violence. Dorcey is one of the founders of Irish women's organisations such as the Irish Gay Rights Movement (founded in 1974) and Irish Women United (founded in 1975).

2. The term "monomyth" was borrowed by Joseph Campbell from James Joyce's Finnegans Wake to describe the concept of a basic narrative pattern of a hero's journey in myths and legends in 1949, The Hero with a Thousand Faces. A further exploration of the traditional quest genre tradition will be discussed later in this essay. socially imposed role and life as wife or mother, subsequently become "bad" by diverging from the traditional patriarchal view of women's role in Irish society, and undergo, ultimately, a transformative inner journey of self-discovery which leads them towards emotional independence and individuality.

The short story genre as a strategic narrative device for Irish women has roots in Ireland's literary tradition and heritage. According to Frank O'Connor, the short story in an Irish literary context is a "natural form" deriving from the Irish storytelling tradition "embedded in the Irish psyche" (Casey 1990: 9), a genre associated closely with Irish history as well as with Irish women's writing. The short story is considered to be a "natural progression of story-telling, letter-writing, diary-keeping, and even school essay-writing", forms of writing with which women were already familiar in their lives (Madden-Simpson 1984: 13, 18). The skills and techniques inherent in the short story medium are also relevant when seeking to reach a broad and diverse audience through printed, visual or social media. ${ }^{3}$ Traditionally, the short story also plays an essential role in Irish culture and politics. ${ }^{4}$

3. Many Irish female writers work or have worked in journalism such as Clare Boylan, Mary Leland (Cork Examiner, Irish Times), Margaret Dolan, Janet McNeill (Belfast Telegraph), Mary Morrissy (Irish Times). Maeve Binchy also wrote columns and features for the Irish Times. Some Irish women work for media broadcasts or drama on television or radio such as Mary O'Donnell as a broadcaster, Marilyn McLaughlin as a BBC Radio Foyle researcher, and Anne Enright as a TV producer with Radio Telefís Éireann. Irish women's stories are also frequently read and broadcasted on radio such as those by Fiona Barr, Mary Beckett, Stella Mahon or Anne Devlin. Anne Devlin's story "Passages" (from 1986, The Way-Paver) was adapted for television as A Woman Calling on BBC2 Northern Ireland in April 1984.

4. Declan Kiberd considers the short story to be "the natural result of a fusion between the ancient form of the folk-tale and the preoccupations of modern literature", holding a particular "appeal for the writers of the emerging Catholic bourgeoisie who hailed from regional towns" (Kiberd 1979: 145). For more see Casey (1990 Introduction), Edge (1998), Boada-Montagut (2003). 
O'Connor argues also that the short story is a vital expressive tool for the "submerged population" of a country, such as Ireland, in a post-colonial state (O'Connor 1963: 20). In the light of Frank O'Connor's view, Colm Tóibín, echoed by Boada-Montagut, connects the prominence of the Irish short story to Ireland's status as a country with a broken and traumatic past. $^{5}$ Tóibín's or Boada-Montagut's association of a political discourse with the short story genre may suggest a reason for the significant appeal of the short story genre within contemporary Irish women's writing. The short story serves Irish women's purpose of expression because, among the submerged population, Irish women as the "Double Other" have actually experienced the legacy of a double dispossession (Edge 1998: 215-6; Boada-Montagut 2003: 10). ${ }^{6}$ Within the maledominated Irish literary canon and tradition, women's writing has tended to be marginalised. ${ }^{7}$ In this essay we suggest that Irish women may find the short story both an effective and also an instinctive way of expressing varied issues related to women as well as a medium which offers fresh scope for women to create a distinctive style of literature, a literature of their own (Boada-Montagut 2003: 38). Apart from the convenience of the short story as a vehicle for expressing a political agenda through an economical, focused, and accessible narrative, the short story was also a practical choice for Irish women, especially before the second half of the twentieth century. At that time women still mostly stayed home as full-time homemakers.

5. Tóibín argues that the limited scope of time and space of the short story genre makes it possible to conveniently omit the part dealing with "the bitterness of the past, the confusion of the present or the hopelessness of the future" (Tóibín 1987: 6-8). Also Boada-Montagut (2003: 35-6).

6. Irish women, according to Sara Edge (1998) and Irene Boada-Montagut (2003), were subordinated to both patriarchal power and to British national identity under British colonization; subsequently, to Irish nationalism, unionism, Catholicism or Protestantism.

7. For more discussion on the connection between gender and genre, see Dinah Birch (1992).
Thus it may be easier for such women to produce a short story than a novel between household chores as well as having a better chance to be published in magazines. ${ }^{8}$

The Irish contexts in which the stories analysed in this essay are set belong to a key period of time during which Irish women's formal status steadily improved through various legal and institutional reforms. In general, Irish feminism has fought vigorously to achieve successfully an enhanced level of equality. This process started in the 1970s and 80 s when Irish women started to gain more representation in politics and, in consequence, were able to promote legal reforms which contributed to the gradual emancipation of women. ${ }^{9}$ Moreover, various sex scandals amongst Catholic clergymen and tragic incidents such as the death of Ann Lovett and the notorious Kerry Babies case in 1984, the Lavinia Kerwick case (1991), or the X Case (1992) shocked the country and, as a result, led indirectly to the subsequent reforms relating to women's options in respect of marriage and reproduction. ${ }^{10}$ However, the eighth amendment of the Constitution of Ireland in 1983, which

8. Both Virginia Woolf and Margaret Lawrence have pointed out the close connection between women's writing and maternal/domestic duties in the traditional home (Woolf 1979: 57; Birch 1992: 43). Some writers, such as Katherine Tynan, chose to write short stories as they were more likely to be published in periodicals, while others like Edith Somerville and Violet Martin wrote them because they could provide an instant income (MaddenSimpson 1984: 13). See Virginia Woolf (1979) and Dinah Birch (1992).

9. The emergence of action groups supporting women was a feature of this period. More women participated in public office and around $21 \%$ of those elected to parliament in 1990s were women, almost double the number of the women elected a decade earlier. Ultimately, in the 1990s, two women, Mary Robinson and Mary McAleese, were elected the president of Ireland. For more see Patrick Clancy, ed, 1995, 2000, Irish Society: Sociological Perspectives; Diamaid Ferriter, 2005, Ireland 1900-2000; Yvonne Galligan, 1998, Women and Politics in Contemporary Ireland.

10. For more see Ferriter (2005) and McCafferty (1987). 
introduced a constitutional ban on abortion, set a backlash in motion. ${ }^{11}$ Nevertheless, in 1995 Irish women took a further step forward by gaining the right to divorce. Subsequently, the Family Law (Divorce) Act was passed and has been in operation in Ireland since $1996 .{ }^{12}$

Many stories published in the period from 1970s to 90s were about women's struggles and personal tragedies and intended as responses to the difficulties faced by women in contemporary society. Irish female writers in the 1980s tend towards a retrospective focus, in terms of narrative context, on the earlier days of struggle for female emancipation in Ireland, suggesting a glimmer of hope against an oppressively dark social background. By the 1990s things have moved on socially and this was also reflected in the way in which stories from this period present more positive heroines and outcomes which demonstrate, through the focus on "quest", an awakening of the female spirit and liberation of the female mind.

\section{The Quest in Irish Women's Stories, 1980 to 2000}

The quest motif in literature, termed the "monomyth" by Joseph Campbell, can be traced far back within western literary tradition.

11. A new sub-section after section 3 of Article 40 was inserted and it reads: "Admhaíonn an Stát ceart na mbeo gan breith chun a mbeatha agus, ag féachaint go cuí do chomhcheart na máthar chun a beatha, ráthaíonn sé gan cur isteach lena dhlíthe ar an gceart sin agus ráthaíonn fós an ceart sin a chosaint is a shuíomh lena dhlíthe sa mhéid gur féidir é" ("The State acknowledges the right to life of the unborn and, with due regard to the equal right to life of the mother, guarantees in its laws to respect, and, as far as practicable, by its laws to defend and vindicate that right"). For the full act of the Constitution of Ireland see the House of the Oireachtas, 13 December 2015, Irish Statue Book. (http://www.irishstatutebook.ie/eli/1996/act/33/ enacted/en/html), online.

12. More details about Family Law (Divorce) Act 1996 see the House of the Oireachtas, 13 December 2015, Irish Statue Book

(http://www.irishstatutebook.ie/eli/1996/act/33/ enacted/en/html), online. For a detailed history of Irish women's movements and achievement, see Clancy (2000), Ferriter (2005) and Joe Cleary and Claire Connolly (2005).
Classical myths present legends of a hero who proves himself by embarking on a journey in which he undertakes a difficult, dangerous task or mission. The life-changing process of this quest prepares the hero on successful return for elevated power and status in his life, whether in the form of a reward (kingship, power or successful courtship), or of self discovery (the truth unveiled). Typical quests are tales such as the Odyssey, the Aeneid, Oedipus Tyrannus, the Ramayana, Perseus, Jason, in all of which a hero ventures forth into a world of supernatural power which is full of danger and challenge. This motif resurfaces in various forms in literature of later periods - the chivalric romance, the Bildungsroman (rite-of-passage novel), fantasy novels or games centre invariably around a quest for growth, development or a task. In classical literature or legends, a hero's quest is a honoured one with promise of reward on successful completion. In the aftermath of a quest, the protagonist returns as a different person with a "reborn self". However, throughout the history of western literature, unlike a hero for whom self fulfilment is the greatest reward, a heroine's quest emphasises often a different manifestation of fulfilment: that is, a process of successful socialisation into a "proper woman" through conforming to the expected social norms of humility and passivity. ${ }^{14}$ For example, in the story of Psyche and Cupid or the story of the grieving mother Demeter's search for her daughter Persephone, the journey is not motivated by the urge to prove one's courage and value but rather by the experience of loss. In such a circumstance the woman (for example, Psyche) has to undertake a series of punitive tests in order to be accepted by her lover. In those stories of a woman's quest, the most valuable reward which can be attained by a woman is often a happy marriage (typically, to be accepted as the wife of a powerful figure). According to Sandra Gilbert

13. The more recent works such as fantasy novels The Hunger Games trilogy (2008) present a more active positive heroine, a counterpart of a hero, in a quest story. However, works such as this fall beyond the scope of this essay which primarily focuses on the works of the twentieth century. 
and Susan Gubar in The Madwoman in the Attic (1979), the consequence of this female rebirth or growth process is not to advance or promote a woman's active participation in life and society but rather to encourage her to embrace passive acceptance of the prevailing social reality. Within a patriarchal society it is inevitable that such a process will involves women's self-denial and suppression of "self" (248-308).

However, contemporary Irish women's stories explored in this essay strive to subvert this tradition of female socialisation and suppression which is characteristic of western literature. The female quest is presented by Irish female writers as a pursuit of selfhood within a framework which depicts aspects of women's isolation, alienation or identification but which leads ultimately to enlightenment. Unlike the traditional quest genre which usually explores the developmental process of a younger hero, Irish women's stories discussed in this essay focus primarily on older or middle-aged women and their transformation. These women are sometimes portrayed as choosing alienation from a comfortable lifestyle and relationship for the sake of embarking on a quest to discover their true selves. They attempt to set themselves free by liberating the suppressed Eros within them as well as by separating themselves from their husbands or their marriage prisons. Stories, such as Éilís Ní Dhuibhne's "Looking", "Estonia" and "Hot Earth" and Clare Boylan's "That Bad Woman", written in the late 1980s and 90s, explore women in their mid-life crises and their attempts to pursue an alternative lifestyle away from their domestic routines and wifely duties at this particular stage of their lives. Some other stories, such as Éilís Ní Dhuibhne's sarcastic allegory "The Search for the Lost Husband", Stella Mahon's "Knock Three Times" and Mary Dorcey's "The Orphan", cover female rebirth quests by way of a self-discovery triggered by a broken relationship or a traumatic past event and such stories evoke explicit female aspirations and willpower. ${ }^{14}$

14. May more Irish women's stories imply that the main female characters are women who are (or manage to) awaken to self-discovery within a $\cdot \%$
Stories about those who fail to fulfill their quest and end up entrapped in despair are more characteristic of writing from the late 1970s and early or mid-80s. ${ }^{15}$ The stories explored in this essay present a more positive outcome of such a quest for self-development. A pervasive motif in these short stories is depiction of a latent drive for liberation of the female spirit which, in some stories at least, results in the heroine transcending an initial state of victimisation and powerlessness. Stories such as those by Boylan, Mahon, Ní Dhuibhne, Dorcey or McLaughlin can be contextualised

.$/$ disllusioned, a broken or a lost relationship, such as Mary Leland's “A Way of Life", Mary Lavin's "In a Café", Clare Boylan's "Life on Mars", Marylin McLaughlin's “A Dream Woke Me”, Éilís Ní Dhuibhne's other stories "Oleander", "Swiss Cheese", "Nomads Seek the Pavilions of Bliss on the Slopes of Middle Age" and "Love, Hate and Friendship".

15. In stories such as Edna O'Brien's "Number 10" or Anne Devlin's "The House", there are descriptions of women in despair, in dilemmas and entrapped, still unfulfilled in their quest for selfdiscovery. Devlin's story deals with ambivalent female anxiety and uncertainty about the desire for independence but the female character ends up disassociating from reality by taking refuge in madness. O'Brien's heroines are often punished for their libido or erotic desire by entrapment in a loveless marriage or by exile. Lucile Redmond's "The Shaking Tree" and Clare Boylan's "Life on Mars", similar to Devlin's "The House" and O'Brien's "Number 10", depict symptoms of a socalled "literary insanity", which can either "finish the [heroine] off entirely or provide the turning point in her quest" (Annis Pratt, et al, 1982, Archetypal Patterns in Women's Literature, Brighton: Harvester, 142). The rebirth journey involves both physical and mental risks that are just as likely to lead to madness as to renewal. These stories describe women's shattered or wounded selves in the aftermath of the loss of their primary source of strength, usually their lovers or husbands, indicating that they seem to have no strength ('self') without emotional support from their male partners. The grief over the loss of love, sometimes leading to mental or physical disorder (like sleepwalking or witnessing phantasmal images or figures), seems to reflect the crisis of a lost or divided 'self' in these female characters in Irish women's stories published in the 1970s and early or mid-80s. 
within the goals and heritage of Irish women's movements during those times of social transformation. Their stories epitomise the impact of women's rights movements spanning the period from the upheaval of the 1960s through to the $80 \mathrm{~s}$, and eventually to the new freedoms and opportunities which came along with the new millennium. Such women writers played a role in liberation from an internalised and institutionalised "false consciousness" cast by the shadow of patriarchy. In this respect Irish women's stories have signaled a new direction and also opened a new page in respect of how women are represented in Irish writing, which to some degree both reinforces and drives forward the ongoing empowerment process of women in Irish society.

\section{Marriage Rebels: Subverting a Female Form}

The modesty and devotion of women as mothers and wives is embedded in Irish culture. This image is closely associated with the worship of the iconic, quiet, suffering mother figure of the Virgin Mary which is rooted in Catholic religious doctrine. A "sacrificial" woman who devotes herself and her needs to her family is also, conveniently, endorsed officially in the public domain within the Irish Constitution. ${ }^{16}$ Responding to this marginalised view of women as mothers and wives, Irish women's stories feature a quest motif in which middle-aged women rebel against their prescribed destiny. These older women strive for what might constitute a purpose, a meaning of life, in their own right. Typically, these female characters embark on a personal quest by distancing themselves from their present, usually secure, lives. They do

16. 1 Subsections 1 and 2 of section 2, article 41 of the Constitution declare clearly: "In particular, the State recognizes that by her [woman's] life within the home, woman gives to the State a support without which the common good cannot be achieved. The State shall, therefore, endeavour to ensure that mothers shall not be obliged by economic necessity to engage in labour to the neglect of their duties in the home". For more see Roinn an Taoisigh (Department of the Taoiseach), 1 May 2015, Bunreacht Na hÉireann (Constitution of Ireland), online. this by going into physical exile or by undertaking an inner journey which eventually gives birth to a sense of personal liberation via transformational artistic creativity. This theme of a female quest for self-discovery and freedom is sometimes located within a surrealistic context or, at times, given an ironic perspective. These older women who have already been through the experiences still awaiting the younger women focus on themselves instead of society's expectations of them, as they embark on a new, probably highrisk, journey to change their lives. This new stage in life is one in which women attempt to negotiate their priorities and options with themselves rather than with external forces, in order to seek fulfillment in their lives. The catalyst for this goal-motivated quest is initiated and accelerated by an urge to liberate a suppressed libido through a creative power and passion latent within these women who are at a stage when they are no longer young, vulnerable or naïve.

Earlier in Maeve Kelly's "A Life of Her Own" (1976), the heroine, who is no longer willing to sacrifice herself for the welfare of her parents, proceeds to create an inner space which allows her to live her own life by taking the marriage vow. This life choice by the woman in Kelly's story might, seen from an alternative perspective, denote a commitment to women's conformity and self-sacrifice by appearing on the surface to fulfil the expected role of a good wife in a 1970-Irish social context. This was a period of time in which women still had limited choices to live their own way of life outside the secure enclosure of marriage. Decades after Kelly's iconic story on women's choice, the women on the quests depicted in the stories by Éilís Ní Dhuibhne, Clare Boylan or Marilyn McLaughlin are individuals who seek to control their own destiny by the opposite strategy of rebelling against this marriage norm and by immersing themselves in an inner journey of selfenlightenment. The marriage rebels in these stories, who have devoted their youthful years to a secure marriage as a dutiful wife or mother, rebel against the sense of alienation they feel within their current marriage enclosure. The psychological development that 
occurs between marriage partners during middle age manifests itself through a feminist lens in Irish women's short stories. These middle-aged women seek to liberate themselves beyond socially determined roles and duties. They do not need to follow the guidance of another female role model as younger women are likely to do. Instead, these older women find empowerment from within to rediscover and revive their own powers through energy and forces of libido.

Ní Dhuibhne's "Estonia" (1997) depicts such a rebellious woman. The central character Emily is disillusioned about her marriage and her husband, who never "bolster[s] up Emily's need for security" (Ní Dhuibhne 1997: 185-6). The hardship of the reality entraps Emily for years in the same dull routine as a working mother, struggling to manage her life with children and unpaid bills. Emily's dissatisfaction and unrest result in daydreaming and complaints which eventually trigger her personal quest, from which she hopes to change the direction of her life. Emily's unrest also elicits forces of libido inside her which give birth subsequently both to her creative inspiration as well as to her buried passion. Both provide Emily with a way to compensate for what is otherwise a trancelike existence. The power which fuels older women in these stories manifests itself in a form of creativity process serving as a way for them to liberate themselves. This catalytic and cathartic energy released by such a process is, according to Harding, equivalent to rebirth, in which a hidden potential power from the psyche is discovered and produces either a new artistic work or a new self (Harding 1971: 2145). The character's artistic inspiration is juxtaposed with her psychological development, and expressed as a female aspiration for liberation and independence. Nevertheless, pursuit of such a goal is not always depicted as being promising. Anne Devlin's heroine in "The House" (1986), for example, fails in her attempt to achieve the goal after embarking on such a process which results ultimately in tragic alienation and madness. Notwithstanding this particular depressing image of a female artist, a decade later Clare Boylan made her character in "That Bad Woman" (1995) regain a lost part of her self through reengaging with an old hobby of photography. Éilís Ní Dhuibhne's heroines in "Hot Earth" and "Estonia" (1997) are also successful in starting new lives as writers. In stories by Irish women in the 1990s, generally more positive images prevail of Irish women's capacity to make their own decisions by comparison with the depictions in short stories of the preceding two decades.

In Ní Dhuibhne's "Hot Earth", Bernadette leaves both her husband and Ireland in order to be independent as a writer. The juxtaposition of the hot and cold climates in Italy and Ireland in this story evokes a contrast between the inner worlds of Bernadette and her husband. Bernadette, a romantic sentimentalist with a yearning for passion and recognition, is attracted to the hot earth while her husband, who appears to be an intelligent rational idealist, is only conscious of the possible damage from the sun and the risk of skin cancer. In this story, the higher temperature in countries other than Ireland is a metaphor for Bernadette's state of mind and desires. The hot climate of Italy evokes Bernadette's passionate side, and acts as a kind of catalyst leading to a confrontation with her problem and an eventual discovery of a self with which she felt fulfilled. In the stories about such rebellious women, a separation from their husbands seems to be a primary and critical catalyst for their personal transformation. Bernadette in Ní Dhuibhne's "Hot Earth", as with the woman in Boylan's "That Bad Woman", embarks on a quest for her own sake driven by a sense of alienation from the inertia of her married life, which, she believes, might be the main obstacle blocking development of her creativity. These women's husbands may not be dreadful figures but their impact as husbands are so rooted in the conventional social norm that these women can no longer feel satisfied with a role which involves the surrender of their selves to a maledominated culture. Furthermore, there seems to be more social discipline imposed upon women than on men to be aware of social expectation of what constitutes appropriate behaviour in various circumstances. In "Hot Earth", Bernadette feels awkward about the way her lover Kevin praises his wife as faithful and loyal as if by contrast Bernadette is bad because she is an unfaithful wife to her own 
husband. Fidelity is a virtue expected more of women than men.

Apart from artistic energy acting as a catalyst to development, the symbol of water plays a significant role in middle-aged women's inner journey. In the wake of early feminist consciousness, Kate Chopin's The Awakening (1899) already showed the female character as liberated when she is immersed in the "female organic element". Elaine Showalter observes that water is used symbolically to represent the "female element" because the female body is apt to wetness such as "blood, milk, tears and amniotic fluid" (81). Showalter goes on to argue that "drowning" in women's writing is a "traditionally female literary death" which also symbolises women's ultimate liberation and return to the source of life (Ibid). The symbolic bodies of water adopted by Chopin in an earlier century recur as a source of liberation in various stories by Éilís Ní Dhuibhne or Marilyn McLaughlin's stories from the late twentieth century. One of Ní Dhuibhne's earlier stories, "Looking" (1988), not only depicted water as a source of energy and regeneration but also presented drowning as a symbolic, transformative process for the female character concerned. Significantly, this story is set against the background of the late 1960s in Ireland in the wake of the new liberalism when the Late Late Show, which debated controversial societal issues, was broadcast on RTÉ. The female character Margaret, a housewife, finds her routine life one of inertia and without a purpose. Margaret's aspiration for a change, a meaning, in her life also emerges in a dream associated with water. The dream is "suffused with light and sweat", in which Margaret is immersed in the joy of a walk by the sea until a "hand" pulls her away from the water source towards a white concrete house "filled with bleakness and despair" (Ní Dhuibhne 1988: 37). The crystal clear water and the warm sunshine, as opposed to the bleakness and sterility of the white house, appear as a source of empowerment towards a potential transformation. "Looking" implies Margaret may have a chance to develop despite the obstacles blocking her from doing so. Margaret's "spiritual death" by literary drowning in "Looking", as in Chopin's The
Awakening, acts as a transition leading to a transformation. This transformation, seen through Margaret's imaginary "gaze" on her life-death struggle in a coma in a hospital ward, may cause symbolic annihilation if it fails while also having the potential for renewal and growth if it succeeds. The symbolic "looking" of the heroine at her life and her self as suggested in the story's title denotes a process of struggle in which women aspire to a different dimension in life.

Another Ní Dhuibhne story "Love, Hate and Friendship" (1997), published a decade later than "Looking", develops the positive association of water with personal development in a story about a woman on a similar quest to that of the character in "Looking" who nevertheless is not required in the later story to undergo literary annihilation through drowning. The later story uses the device of a dream in which the main character, Fiona, is chased and embraced by waves of the sea. This dream empowers her to face herself as well as her problem. The waves appear as symbols of powerful forces in the unconscious, as well as of the power of the self. In the beginning of the story, Fiona is described as surrendering herself to her love for Edward, her husband. Fiona's mind is always preoccupied with Edward even in the absence of his physical presence as if "Edward colonised her territory. Everywhere she looked in Ireland reminded her of him. He had taken over every place and every object in her life" (Ní Dhuibhne 1997: 36). Fiona attempts to liberate herself from this troubled relationship because she finds no place for herself in the unbalanced bond with Edward. Therefore Fiona attempts to detach herself from the situation by travelling to the warm south of France, a contrast to cold Ireland. Again, the stark contrast of the climate between that of cold, frigid Ireland and that of warm, vibrant France mirrors the two conflicting elements which define Fiona's life - one stable but under the shadow of a tyrannical lover; the other adventurous and uncertain but with freedom. Once again, Fiona chooses eventually to follow her own way towards a life of freedom. In the last paragraph of the story, Fiona walks into the water and she feels warm and free, relaxed as if on a holiday. Immersed 
in the water, Fiona is finally able to re-focus on herself and on the way she wishes to live her life.

The water metaphor also features in some of Marilyn McLaughlin's stories. In "A Dream Woke Me" (1999), water plays a role in the character's struggle to break away from her emotional dependence on her lover, now dead. The woman's house in the story is haunted by a huge muscular tree, which was a gift from her dead lover. It reflects the shadowy state of mind and sense of emptiness of the anonymous female character in the aftermath of her lover's death. The meaninglessness and inertia of this situation put her into a trancelike state expressed in the story as "two drowning lovers - the house clasped by the tree, being drawn down, down, down to its ending. I'll be dead before that happens" (McLaughlin 1999: 4). The strangling of the house by the overgrown tree symbolises the way in which the self of the heroine (like the house) is overshadowed, or swallowed, by the symbol of her phantom lover (the destructive, "carnivorous" tree). However, the heroine eventually survives the struggle, and restarts a new life. This heroine's aspiration is expressed through a "Camelot" dream vision at the end of the story. The dream recalls Alfred Lord Tennyson's romantic verses "The Lady of Shalott" (1842), narrating a woman's tragic aspiration for love. But unlike the Lady of Shalott, the heroine in McLaughlin's story reveals that her goal in making the journey on her own is not a search (nor a sacrifice) for her beloved but for something else, something more important her own Self:

I'll not overlook his blond and curling hair, or sail by his steady blue regard. I make no effort, and float along quite lazily, down to Camelot, maintaining only an edge of watchfulness. It will be pleasant to get to birdman, but it is also pleasant to make the journey. (McLaughlin 6)

The journey in the dream suggests a powerful female quest for self-discovery. The river, representing a source of power, will lead the heroine to the symbolic ideal.

The rebellious women in stories discussed here are not radical martyrs and nor do they break away completely from their husbands, lovers or married lives. Nevertheless, they do not remain unchanged in their minds. They return with a different perspective, enabling them to re-evaluate and refocus their lives as well as their relationships. In "Hot Earth", Bernadette decides for herself what will be the future focus of her life and accepts her husband's love as "loyal and enduring, if not very passionate" (Ní Dhuibhne 1997: 121). Emily in "Estonia" experiences once more a gush of "calm, wifely love" for her husband and the smile which "breaks out on her face is uncontrollable, delighted" as they are true feelings toward her husband (Ní Dhuibhne 1997: 199). In "That Bad Woman", there is a huge transformation both of the heroine's appearance and of her temperament -her figure is "better defined and her step had grown jaunty" (Boylan 2000: 234). These women have become more aware of their situations and of themselves and now they take responsibility for themselves and play an active and decisive role in defining the direction of their lives.

\section{Reclaiming a Lost Self}

The aforementioned stories are about those who venture out of their comfort zone of a protected enclosure of marriage, and initiate a new direction of their lives. Despite their secure lives such women have the urge to discover an authentic life of their own. The women depicted in the following stories, by contrast, are not so fortunate as those middleclass, wealthier housewives discussed in the previous section. They are those who live on the fringe of society. These women survived harsh experiences of abuse and exploitation by hideous, demonic male figures in their past. These stories, reflecting a symbolic process through which women heal a wounded or regain a lost self, are best exemplified by Mary Dorcey's “The Orphan”(1997), Stella Mahon's "Knock Three Times" (1985) and Éilís Ní Dhuibhne's "The Search for the Lost Husband" (1997). Despite being written years apart and by different writers in different regions, the first two stories display remarkable parallels in terms of structure and plot. Both stories are about a traumatised woman who revisits her childhood home in order to confront the ghosts from her past, which continue to haunt her current life. By confronting the deepest fears in 
her mind, the woman is eventually able to move on to live a new life of her own. In other words, these female characters achieve the annihilation of the false self that blocks them from moving on with their lives.

Dorcey's "The Orphan" represents an iconic and symbolic response to Irish women's victory in respect of marital choice as the outcome of the divorce referendum of 1995. This story is an allegory expressing a triumph over the dysfunctional family and domestic abuse for which Ireland was once notorious. The official legalisation of divorce in 1995 granted a second chance in life to many women who used to be victims of an abusive marriage. Against a background of gradual progression in respect of liberation for women in the choice of marriage, the character in the story is eventually able to liberate herself from a trauma she underwent long ago. Just like some women who seek to break out of a disastrous marriage through divorce, what this heroine seeks to fight against is a demon self which has occupied and replaced her own. This false self which the female character in Dorcey's "The Orphan" confronts is a self-blaming individual deformed by sexual abuse (child prostitution) experienced in her childhood. This oppression reinforces a sense of self-loathing, which she shows when she reasons that she "must be an evil person to have brought this upon [her]self...there must be some kind of stain on [her] that [her] father could see that made him act the way he did" (Dorcey 1997: 117).

A similarly distorted perception of selfblame is sometimes imposed upon the female victim of rape by a view that she (the victim) is the one who is responsible for the outcome. In Mahon's "Knock Three Times", the female character is similarly torn by traumatic experiences from her childhood. She regrets that she surrenders her own values in exchange for recognition among her peers or, later, for material survival when she recalls that she "sold [her] soul and killed a rat" and "sold [herself] for a colour TV" (Mahon 1985: 17-8). Her anxiety seems to be associated with a disturbing, nightmarish trauma or complex rooted in her girlhood when her "secret place" was intruded upon by a "Scrunchy Man". It is not clear from the text whether this female character had been sexually assaulted when she was a little girl but there might be hints of this in the description of the dreadful male figure: "your leering eyes, your mouth that grins wetly at me. See your hand with its brown-stained finger point at me, choose me, reach for me. Not this time" [italics mine] (Mahon 1985: 19). Or perhaps at some other time she was attacked or molested? Nonetheless, the female character is so entrapped by this past trauma that she cannot take any action to move on in her own life. Symbolically, this dreadful figure, the "Scrunchy Man", is the shadow the female character must overcome in order to regain her self.

Eventually both the female characters in "The Orphan" and "Knock Three Times" achieve the goal of liberating themselves successfully. By "knocking at their door, she had knocked at her own, and found, in truth, that no one was barring her way. She can walk in" (Mahon 1985: 20). Similarly, the female character in Dorcey's "The Orphan" comes to realise the oppression she has experienced and discovers her self in the process:

I was an orphan. Everyone knew that. I belonged to no one, and so I belonged to everyone. That's what he used to say...I know he was wrong. I belong to someone. I have my house. I have my children. And I belong to myself (Dorcey 1997: 129-30).

Both Dorcey's and Mahon's stories appear not only political but realistic in uncovering a dark corner revealing serious social issues of sexual abuse, exploitation and poverty within a dysfunctional, male-dominated Irish family and society. In the late 1990s, likewise, Ní Dhuibhne's "The Search for the Lost Husband" depicts the female character's ultimate rejection of, instead of reunion with, her tyrannical husband and suggests that women eventually wake up to themselves and make their own choice. It is a parody of a typical patriarchal fairy tale with a so-called happy ending where a vulnerable maid is rescued and lives with her Prince Charming happily ever after. This story, an adapted retelling of an old Irish tale "The Little White Goat", centres around a quest for herself. As in the story of Psyche, the heroine must obey commands given to her by her lover - in this case, not to shed a tear - otherwise her lover would leave her. This heroine's quest starts with a search 
for her lover whom she has lost due to her "mistake". This mishap was to disobey the rule imposed by her lover in their relationship. However, the quest ends in self-discovery, in abandoning the abusive lover and in beginning a new life of her own. In Ní Dhuibhne's story, the woman is capable of outgrowing her vulnerability and with the capacity eventually to exorcise from her self the magic spell cast on her by the goat-man, an exorcism which enables her to make the choice to finish the relationship with him. Ní Dhuibhne's storyline in "The Search for the Lost Husband", a theme which runs through the whole story collection of Inland Ice (1997), is one of rejection by the female of the male's concept of happiness as when the female character declares: "Because it's time for me to try another kind of love. I'm tired of all that fairytale stuff" (Ní Dhuibhne 1997: 262).

In summary, the female journey of development toward selfhood depicted in Dorcey's, Mahon's and Ní Dhuibhne's stories is an optimistic one, with the possibility of a positive outcome for the self-esteem and individuality of their female characters. The recurrent motif of female quest is the vehicle through which women overcome the shadow cast by the forces of social conformity, a shadow which evokes in women a sense of self-hatred and denial of their own bodies and minds and also blocks women's capacity to discover their "self".

\section{Conclusion: Reading Irish Women's Short Story as a Feminist Genre}

The stories examined in this essay demonstrate the use of a specific motif of "quest for self discovery" as a vehicle for empowering women to seek liberation in their own terms. The use of this motif is also subject to a kind of feminist evolution within the corpus of stories. They depict an explicit rebellion against aspects of patriarchal ideology and the Irish social system, such as the male-dominated marriage institution or suppressed female sexuality. This essay argues that a noticeable level of feminist awareness is represented by the manner in which Clare Boylan, Éilís Ní huibhne, Stella Mahon, Mary Dorcey and
Marilyn McLaughlin construct their characters and plots in order to express their perspectives despite the constraints imposed by contemporary, socially self-censoring, public norms in Ireland about certain issues. It would be, however, an oversimplification to suggest that Irish female writers in general have used their stories as mere propaganda tools to serve a particular feminist political agenda, even though this is certainly the case with Mary Dorcey and her stories. In addition, it is not the purpose, nor within the appropriate scope of this essay, to claim that Irish women's writing serves as a synonym for Irish feminist writing. Nonetheless, there is a strong case for evaluating contemporary Irish women's short stories from a feminist perspective. The Irish critic Janet Madden-Simpson has claimed that "most Irish women writing [is] feminist" in the light of the awareness with which Irish female writers have clearly expressed the experience and difficulties of being women as well as writers in Ireland, who "approached their subjects from a more crusading and analytical angle" (Madden-Simpson 1984: 11). Ailbhe Smyth argues that Irish women who in and through their writing refuse to accept the socalled truths imposed upon them by society are, by definition, subversive (Smyth 1989: 14). Christine St. Peter echoes Smyth's view on Irish women's quests to subvert through their writing. St. Peter goes on to argue further that Irish women's writing can be termed feminist, since the precondition of feminist writing "assumes conscious political decision" with the focus on the "refusal and subversion of received orthodoxy, to say nothing of an appeal to extra-textual 'truthfulness and authenticity", (St. Peter 2000: 153). Although it may be debatable whether one can classify Irish women's short stories as the kind of conscious political expression to which Christine St. Peter referred, the characteristics of subversion and rebellion in some contemporary Irish women's short stories still appear feminist insofar as they seek to challenge a patriarchal ideology and socially imposed pre-ordained roles for women within an Irish context. 


\section{Works Cited}

Birch, Dinah. 1992. "Gender and Genre". Imagining Women: Cultural Representations and Gender. Cambridge: Polity Press.

Boada-Montagut, Irene. 2003. Women Write Back: Contemporary Irish and Catalan Short Stories in Colonial Context. Dublin: Irish Academic Press.

Bourke, Angela. 2002. The Field Day Anthology of Irish Writing. Vol. V. Cork: Cork University Press.

Boylan, Clare. 2000. Collected Short Stories. London: Abacus Press.

Campbell, Joseph. 2008. The Hero with a Thousand Faces. Novato, California: New World Library.

Casey, Daniel. 1990. Introduction. Stories by Contemporary Irish Women. New York: Syracuse University Press.

Clancy, Patrick, ed. 1995, 2001. Irish Society: Sociological Perspectives. Dublin: Institute of Public Administration.

Cleary, Joe and Claire Connolly, eds. 2005. The Cambridge Companion to Modern Irish Culture. Cambridge: Cambridge University Press.

Dorcey, Mary. "The Orphan". 1997. If Only. Eds, Kate Cruise O'Brien and Mary Maher. Dublin: Poolbeg Press.

Edge, Sara. 1998. "Representing Gender and National Identity". Rethinking Northern Ireland. London: Longman.

Ferriter, Diarmaid. 2004, 2005. Ireland 1900-2000. London: Profile Books Ltd.

Galligan, Yvonne. 1998. Women and Politics in Contemporary Ireland: From the Margins to the Mainstream. London: Pinter.

Gilbert, Sandra M. and Susan Gubar. 1979. The Madwoman in the Attic. New Haven: Yale University Press.

Harding, Mary E. 1971. Women's Mysteries: Ancient and Modern. New York: Harper \& Row.

Kiberd, Declan. 1979. "Story-telling: The Gaelic Tradition". The Irish Short Story. London: Smythe.

Madden-Simpson, Janet. 1984. Introduction. Woman's Part: An Anthology of Short Fiction by and About Irish Women 1890-1960. Dublin: Arlen House.

Mahon, Stella. "Knock Three Times". 1985. The Female Line: Northern Irish Women Writer. Ed, Ruth Hooley. Belfast: Northern Ireland Women's Rights Movement.

McCafferty, Nell. 1987. A Woman to Blame: the Kerry Babies Case. Dublin: Attic.

McLaughlin, Marilyn. 1999. A Dream Woke Me and Other Stories. Belfast: The Blackstaff Press.

Ní Dhuibhne, Éilís. 1988. Blood and Water. Dublin: Attic Press. . The Inland Ice. 1997. Belfast: The Blackstaff Press.

O'Connor, Frank. 1963. The Lonely Voice. London: Macmillan.

Roinn an Taoisigh (Department of the Taoiseach). 27 May 1999. Bunreacht Na hÉireann (Constitution of Ireland). Online. Internet. 6 February 2015. Available $<$ http://www.irishstatutebook.ie/en/constitution/ index.html\#article41

Showalter, Elaine. 1994. Sister's Choice: Tradition and Change in American Women's Writing, Oxford: Oxford University Press.

Smyth Ailbhe. 1989. Introduction. Wildish Things: An Anthology of New Irish Women's Writing, Dublin: Attic Press.

Somerville-Arjat, Gillean and Rebecca E. Wilson, eds. 1990. Sleeping with Monsters. Dublin: Wolfhound.

St. Peter, Christine. Changing Ireland: Strategies in Contemporary Women's Fiction. 2000. Basingstoke: Macmillan.

Tóibín, Colm. 1987. Martyrs and Metaphors: Letters from the New Island. Dublin: The Raven Arts Press.

Woolf, Virginia. 1979. Women and Writing. London: The Women's Press.

Received 19 November 2015 Last version 3 January 2016

Ann Wan-lih Chang was born in Taipei and now lives in Kaohsiung. She received her M.A. from the Queen's University of Belfast in 1997 and her Ph.D. in contemporary Irish women's literature from the University of Ulster in 2006. Her major fields of study and research are contemporary Irish women's writing and the short story genre. She is currently an assistant professor at the Department of Applied English of Shih-chien University, Kaohsiung Campus, Taiwan. 